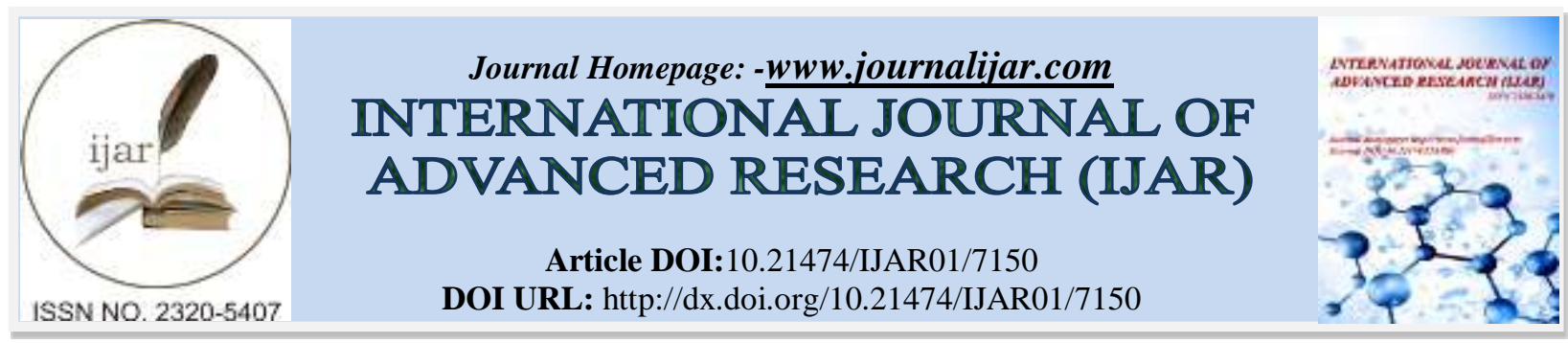

RESEARCH ARTICLE

\title{
GENESIS OF KASHMIR PROBLEM AND POSSIBLE SOLUTIONS.
}

Parveena Akhter and Altaf Hussain Wani.

1. Dept of Education Senior Assistant Professor (Govt. Degree College for women Anantnag Kashmir).

2. Dept of history Assistant professor (Govt. Degree College for women Anantnag Kashmir).

\section{Manuscript Info}

Manuscript History

Received: 20 March 2018

Final Accepted: 22 April 2018

Published: May 2018

Keywords:-

ccession, Kashmiri, Lal Chowk, Maharaja and Terrorist.

\section{Abstract}

Right before the independence of India and Pakistan, princely states were given an option to merge either of the two dominions. One among the states, Kashmir failed to make the decision till raiders entered the area and Maharaja desperate for help approached India for that, readily India accepted to extend its help to Maharaja against the raiders but on a condition to sign the instrument of accession with India. Finding no other way Maharaja signed it and Indian forces entered the Kashmir. The charge of signing the instrument of accession under duress and on the condition that accession to be settled by reference to the people after the restoration of law and order is the edifice to the burning issue besides the failure of UN and Nehru's repeated promises of plebiscite.

Copy Right, IJAR, 2018,. All rights reserved.

\section{Introduction:-}

Maharaja's delay in deciding the future of J\&K, his signing the instrument of accession with India under duress and the conditional accession with India. Sheikh Mohammad Abdullah's welcome to the arrival of Indian army into Kashmir. His encouragement to Maharaja for an accession with India and his impassioned speech to the Security Council of the UN in Feb. 1948, labeling Pakistan as a source of encouragement to tribals to invade Kashmir formed the basis of the longest running unsolved problem in the history of the world. In the aftermath of Maharaja's conditional accession of $\mathrm{J} \& \mathrm{~K}$ to India following the tribal raid, PandithJ.L.Nehru assured the Kashmiris at historic Lal Chowk in Srinagar that they would be given the right to determine their own future soon after the restoration of peaceful conditions in the state. Delhi initially became the strong advocate of the right of self-determination for the people of the state at the UN. The issue was internationalized by Nehru himself after he took it to UN. Nehru was explicit in his commitment for the withdrawal of the Indian forces from J\&K that had landed in Kashmir for driving out the aggressor. Notwithstanding his role in standing forth as the champion of the Kashmiris right to decide their own political future, ironically later Nehru left no stone unturned in denying the same to them. That he did so deliberately with the sole object of seeking political aggrandizement of the land with which he had familial and emotional bonds, is particularly illustrated by his well thought out scheme conceived long before the partition of India. The course of events after the tribal raid gave him an added strength to implement his plan in a most subtle manner. On one hand Nehru was playing safe but on the other hand Jinnah did several mistakes. His refusal to accept Mountbatten as the joint Governor General of India and Pakistan made him feel Mountbatten's anger, who in no time changed the boundary commission line and Gurdaspur a Muslim majority area was assigned to India which became a sole source of communication for India to Kashmir. 
Muslim league always failed to own the Kashmiri Muslims as a part of Muslim state-Pakistan. Except a visit to Kashmir by Jinnah in 1944, on all other occasions Muslim League leadership failed to carve out an image in Kashmir among Kashmiri leadership. Nehru however showed extraordinary interest in striking contrast to Mohamed Ali Jinnah in the Muslim politics of Kashmir during the heyday of the Kashmiris struggle against the autocratic rule of the Maharaja. This served to cement his ideological ties with the then undisputed leader of the Kashmiri Muslims, Sheikh Mohammad Abdullah. Undoubtedly among several other factors Sheikh Abdullah's association with Nehru particularly brought about the ideological orientation of his party in accordance with the principles of nationalism, socialism and secularism. Further Nehru encouraged Kashmiris to take pride in calling themselves Kashmiri Muslims and Kashmiri Pandits rather than Kashmiris. This was done in order to infuse a certain degree of national sentiment with their religious identities. Kashmiriyat was popularized to counter essentially the influence of the two nation theory of the Muslim League on Kashmiri Muslims. Considering Nehru's tacit support for nurturing the idea of Kashmiri nationalism, Sheikh Abdullah had somehow come to believe that without Nehru he would not be able to secure a position of honor and dignity for the Kashmiris in the comity of nations. This is why he sought the resolution of the conflict within the framework of the Indian constitution as early as in 1952 after signing the Delhi Agreement. This was a political blunder fraught with serious implications for the future of J\&K. Not only did Delhi agreement provide a constitutional base to Delhi for interfering with the rights of the people of J\&K, it was a direct affront to the Kashmiri leaders living in the other part of J\&K that neither they nor the people living there mattered in a just and honorable settlement of the Kashmir issue. Notwithstanding 25 seats reserved for POK in the state assembly. The Delhi Agreement gave defacto acquiescence to the division of the state on the ideological grounds of the state power in India and Pakistan. Further the inclusion of the Article 370 in the Indian constitution guaranteeing the autonomy of $\mathrm{J} \& \mathrm{~K}$ instead of being a lasting solution proved to be not more than nightmare in view of Sheikh Abdullah's dismissal as the PM of J\&K soon after the Delhi Agreement. The main objective of Delhi in removing the Sheikh Abdullah was to strengthen its hold on Kashmir by way of extending the jurisdiction of central laws to J\&K at the cost of autonomy. Sheikh Abdullah therefore had no alternative but to invoke the UN resolution passed earlier in support of granting the right of self-determination to the people of J\&K for deciding their political future. The plebiscite front founded by Mirza Afzal Beg in 1955 under the Sheikh Abdullah's patronage challenged the sovereignty of the Indian state in J\&K. Kashmir was thus once again brought to the forefront of international arena. However, following the emergence of Bangladesh and Shimla Accord resulting in relegating the Kashmir issue to a mere bilateral affair between India and Pakistan, Sheikh Abdullah once again turned to Delhi in the hope of securing a respectable position for his nation. However, he sufficed himself by accepting the office of the CMship through the Accord which he concluded with Indira Gandhi in 1975. Once again Sheikh Abdullah failed to achieve anything for his nation even he failed to restore the constitutional position of J\&K as it existed pre1953. Behind the emergence of the militant movement in J\&K was not simply the election rigging of 1987, but the deep-rooted discontent of the Kashmiri Muslims against the Indira-Sheikh Accord. True the Accord created a semblance of political stability in J\&K for the first time after the partition vis-à-vis greater partition of Kashmiri Muslims in the Assembly and Parliament elections. But the ballot was used by the Kashmiri Muslims with the main aim of asserting their distinct identity as against Indian identity symbolized by the mainstream nationalist parties like the state congress. Notwithstanding the treacherous role attributed by the common kashmiri Muslims to Sheikh Abdullah for giving up the demand for a plebiscite, the lesser evil the national conference as compared to the state congress was voted into power by the masses with a hope against hope. But for this undercurrent of aversion to the idea of recognizing the Accord as a final settlement of the Kashmir problem there would have been no sudden turn-over of public opinion against Delhi and the policies of the National Conference in the aftermath of the emergence of militancy in 1989. The emerging point is that the ongoing militancy in J\&K is not simply a Pakistan sponsored enterprise but a movement deep-rooted in the ebb-tide of the Kashmir's struggle against the Indian presence in J\&K. The brute force had left a deep imprint by making people observe 26Jan and 15August as the black days. The data below shows overall fatalities since1990 in Kashmir with militancy related violence.

\begin{tabular}{|l|l|l|l|l|l|l|l|l|l|l|l|l|l|l|}
\hline year & $\begin{array}{l}199 \\
0\end{array}$ & 199 & $\begin{array}{l}199 \\
2\end{array}$ & $\begin{array}{l}199 \\
3\end{array}$ & $\begin{array}{l}199 \\
4\end{array}$ & $\begin{array}{l}199 \\
5\end{array}$ & $\begin{array}{l}199 \\
6\end{array}$ & $\begin{array}{l}199 \\
7\end{array}$ & $\begin{array}{l}199 \\
8\end{array}$ & $\begin{array}{l}199 \\
9\end{array}$ & $\begin{array}{l}200 \\
0\end{array}$ & $\begin{array}{l}200 \\
1\end{array}$ & $\begin{array}{l}200 \\
2\end{array}$ & $\begin{array}{l}200 \\
3\end{array}$ \\
\hline $\begin{array}{l}\text { Terrorist } \\
\text { s killed }\end{array}$ & 183 & 614 & 873 & $\begin{array}{l}132 \\
8\end{array}$ & $\begin{array}{l}165 \\
1\end{array}$ & $\begin{array}{l}133 \\
8\end{array}$ & $\begin{array}{l}119 \\
4\end{array}$ & $\begin{array}{l}117 \\
7\end{array}$ & $\begin{array}{l}104 \\
5\end{array}$ & $\begin{array}{l}118 \\
4\end{array}$ & $\begin{array}{l}180 \\
8\end{array}$ & $\begin{array}{l}285 \\
0\end{array}$ & $\begin{array}{l}171 \\
4\end{array}$ & $\begin{array}{l}154 \\
6\end{array}$ \\
\hline $\begin{array}{l}\text { Soldiers } \\
\text { killed }\end{array}$ & 132 & 185 & 177 & 216 & 236 & 297 & 376 & 355 & 339 & 555 & 638 & 590 & 469 & 338 \\
\hline $\begin{array}{l}\text { Civilians } \\
\text { killed }\end{array}$ & 862 & 594 & 859 & $\begin{array}{l}102 \\
3\end{array}$ & $\begin{array}{l}101 \\
2\end{array}$ & $\begin{array}{l}116 \\
1\end{array}$ & $\begin{array}{l}133 \\
3\end{array}$ & 840 & 877 & 799 & 842 & $\begin{array}{l}106 \\
7\end{array}$ & 839 & 658 \\
\hline
\end{tabular}




\begin{tabular}{|l|l|l|l|l|l|l|l|l|l|l|l|l|l|l|}
\hline year & $\begin{array}{l}200 \\
4\end{array}$ & $\begin{array}{l}200 \\
5\end{array}$ & $\begin{array}{l}200 \\
6\end{array}$ & $\begin{array}{l}200 \\
7\end{array}$ & $\begin{array}{l}200 \\
8\end{array}$ & $\begin{array}{l}200 \\
9\end{array}$ & $\begin{array}{l}201 \\
0\end{array}$ & $\begin{array}{l}201 \\
1\end{array}$ & $\begin{array}{l}201 \\
2\end{array}$ & $\begin{array}{l}201 \\
3\end{array}$ & $\begin{array}{l}201 \\
4\end{array}$ & $\begin{array}{l}201 \\
5\end{array}$ & $\begin{array}{l}201 \\
6\end{array}$ & $\begin{array}{l}201 \\
7\end{array}$ \\
\hline $\begin{array}{l}\text { Terrorist } \\
\text { s killed }\end{array}$ & 951 & 100 & 599 & 492 & 382 & 242 & 270 & 119 & 84 & 100 & 110 & 113 & 165 & 142 \\
\hline $\begin{array}{l}\text { Soldiers } \\
\text { killed }\end{array}$ & 325 & 218 & 168 & 121 & 90 & 78 & 69 & 30 & 17 & 61 & 51 & 41 & 88 & 54 \\
\hline $\begin{array}{l}\text { Civilians } \\
\text { killed }\end{array}$ & 534 & 521 & 349 & 164 & 69 & 55 & 36 & 34 & 16 & 20 & 32 & 20 & 14 & 43 \\
\hline
\end{tabular}

*data till 27 August 2017

New phase of militancy:-

The new flip to Kashmir problem emerged out after 2008. The movement which was restricted to youth militant cadres mostly outsiders, now shifted its gear to people in general who now went out to streets with bare hands to search out independence. The movement intensifies after every year. Now the movement didn't remain confined to Hurriyat. The movement which was extinguishing before 2008 was brought into limelight by the Kashmiri youth by joining militant groups who appealed people and in no time generated an overwhelming mass bass. According to the police estimate, Burhan wani (Hzib commander) had recruited over 80 youth to Hizb terrorist group in 2016 mostly from pulwama, Shopian and Kulgam This contemporary movement is not only confined to $5 \%$ people as claimed by the politicians nor is it because of unemployment only but because of the mistrust of kashmiris over Delhi and the non-fulfillment of the promises made to kashmiri people by the successive governments of both India and Kashmir respectively.

Data of youth joined militant groups' since 2010

\begin{tabular}{|l|l|l|}
\hline Number of youth joined militants & Year in which joined/killed & Number of militants killed \\
\hline 54 & 2010 & 270 \\
\hline 23 & 2011 & 119 \\
\hline 21 & 2012 & 84 \\
\hline 16 & 2013 & 100 \\
\hline 53 & 2014 & 110 \\
\hline 66 & 2015 & 113 \\
\hline 88 & 2016 & 165 \\
\hline 80 & 2017 & 142 \\
\hline
\end{tabular}

*data till august 27, 2017

\section{Suggestions to improve the situation:-}

1. Special status of $\mathrm{j} \& \mathrm{k}$ under article 370 to be continued.

2. Restoration of pre-1953 offices of sadr-i-riyasat and P.M

3. Fair compensation to the state for the power generation in the state by using its waters.

4. Introduction of employment generated schemes and establishment factories in the state to provide employment to the youth. Special provisions for private sector and development of tourism.

5. Fair policies to provide healing touch to the families suffered through militancy.

6. Re-appraisal of Disturbed Areas Act (DDA) \& AFSPA from the state.

7. Review of central acts and articles of Indian constitution extended to the state after 1953.

8. Provisions for the spots development of the state.

9. Setting up of more communication connections with valley.

10. Non use of pellet guns against the demonstrators, instead use of non-lethal ways/weapons to hold them back.

11. Govt, Army and Police to conduct special programmes and seminars to make youth aware about the non violence, peace its benefits and malicious nature of terrorist organizations.

\section{Conclusion:-}

The facts related to contemporary history bear an elaborate testimony to Kashmiris open defiance of the Indian rule. If there exists a semblance of government authority in the state, such a phenomenon rests more on the exhibition of brute force 4 rather than on popular vote. The governments that have come to power in J\&K during and after the period of militancy have neither enjoyed popular support nor a modicum of respect. Majority opinion dubs them as stratocracies rather than democracies. But for that sad reality alone unabated violence taking a heavy toll of human 
life would not have become the order of the day. Thus if order or in other words peace in objective terms is to be restored in J\&K, the Kashmir problem needs to be solved through a meaningful dialogue in the right earnest by three parties viz; India, Pakistan and Kashmiries.

\section{References:-}

1. Kashmir's fight for freedom (Yusuf Saraf)

2. Cultural and political history of Kashmir vol,3 (PNK Bamzia)

3. Heritage of Kashmir, edited by F.M.Hassnain

4. Article 370, A constitutional History of J\&K (A.G.Noorani)

5. The History of Struggle for Freedom in Kashmir (P.N.BAZAZ)

6. Crises of Kashmiri Muslim: spiritual \& intellectual (M.Ishaq.Khan)

7. Inside Kashmir, (P.N.BAZAZ)

8. Kashir (G.M.D SUFI)

9. GreaterKashmir.com

10. Ukessays.com

11. Ministry of external affairs report 2017 